\title{
SIGNIFICANCE OF ADDITIONAL CHROMOSOMAL ABNORMALITIES FOR THE OUTCOMES AFTER THE SECOND LINE NILOTINIB THERAPY IN THE CHRONIC MYELOID LEUKEMIA PATIENTS
}

\author{
I.V. Dmytrenko*, Zh.M. Minchenko, V.V. Fedorenko, I.S. Dyagil \\ NATIONAL RESEARCH CENTER FOR RADIATION MEDICINE OF THE NATIONAL ACADEMY \\ OF MEDICAL SCIENCES OF UKRAINE, KYIV, UKRAINE
}

\begin{abstract}
Background. There is limited information about impact of additional chromosome aberrations (ACA) on the efficacy of the $2^{\text {nd }}$ line nilotinib therapy.

Objective. The aim of the study was to analyze significance of ACAs for the outcome after second line tyrosine kinase inhibitors (TKI) therapy with nilotinib in the chronic myeloid leukemia (CML) patients, who experienced previous imatinib therapy failure.

Methods. The CML patients in chronic phase treated with nilotinib after imatinib failure were analyzed for outcomes.

Results. Among a total of 114 patients, 18 patients (15.8\%) had ACAs at the beginning of the $2^{\text {nd }}$ line therapy with nilotinib. Seven patients (38.9\%) of 18 had variant translocations and 11 patients (61.1\%) had other chromosomal abnormalities in addition to t(9;22), known as clonal evolution. Complete cytogenetic response (CCR) at 12 months was achieved in 37.5\%, 42.8\% and $45.5 \%$ ( $p=0.842)$ of patients with classic $t(9 ; 22)$ translocation, variant translocations and ACAs respectively. In the patients with variant translocations $t(9 ; V ; 22)$ or clonal evolution treated with nilotinib after the imatinib failure, the CCR and major molecular response (MMR), event free survival (EFS), progression free survival (PFS) and overall survival (OS) rates did not differ from those in the CML patients with $t(9 ; 22)$ only. At the same time quantitative characteristics of leukemic and ACA clones had prognostic value for CCR. The increased number of Ph-positive cells and the number of cells with the ACA at the start of nilotinib therapy reduced the probability of CCR.

Conclusions. Higher nilotinib inhibitory activity compare with imatinib allows us to overcome imatinib resistance in the CML patients regardless of the ACA presence at the beginning of nilotinib therapy.

KEY WORDS: additional chromosomal aberrations; chronic myeloid leukemia; nilotinib; second line of TKI therapy; prognosis; resistance.
\end{abstract}

\section{Introduction}

Reciprocal translocation $\mathrm{t}(9 ; 22)(\mathrm{q} 34 ; \mathrm{q} 11.2)$, also known as Ph-chromosome, leads to the formation of the $B C R / A B L 1$ fusion gene, which is considered to be the main pathogenetic event of chronic myeloid leukemia (CML) [1].

However, additional chromosomal abnormalities along with the classical translocation $t(9 ; 22)$ have been described in some patients with CML. These are usually either variant translocations or additional chromosome aberrations (ACAs). In case of variant translocation $(t(9 ; \mathrm{V} ; 22))$, more than two chromosomes are involved in the formation of $t(9 ; 22)$. ACAs include any numerical or structural chromosome aberrations in addition to $\mathrm{t}(9 ; 22)$ and are called clonal evolution. At the time of diagnosis, the *Corresponding Author: Iryna V. Dmytrenko, National Research Center for Radiation Medicine of the National Academy of Medical Sciences of Ukraine, 119/121 Peremoha Avenue, Kyiv 03115, Ukraine.

E-mail: iryna.v.dmytrenko@gmail.com frequency of ACAs is $5-10 \%$ in the patients with chronic phase CML and increases up to $30 \%$ and $80 \%$ in the patients with acceleration phase or blast crisis [2, 3]. A de-novo gain of ACA during the therapy is also possible. It is established that ACAs confer a BCR/ABL-independent mechanism of resistance to the therapy with tyrosine kinase inhibitors (TKI) [4]. Although, currently, there is no final consensus about the predictive value of ACAs, most authors point out that the outcome of imatinib-treated patients with ACAs is significantly lower than of those without ACAs $[5,6]$.

It has been proved that nilotinib (the second generation TKI) is effective in patients with CML after imatinib failure $[7,8]$. But the influence of nilotinib on leukemic clones with additional chromosomal abnormalities has not been determined.

The objective of this study was to analyze the significance of ACAs for the outcome after second line TKI therapy with nilotinib in the CML 
patients, who experienced previous imatinib therapy failure.

\section{Methods}

A retrospective study of $114 \mathrm{CML}$ patients in chronic phase treated with nilotinib after imatinib failure was conducted. All patients were monitored at the Department of Radiation Onco-Hematology and Stem Cell Transplantation of the Institute of Clinical Radiology at the National Research Center for Radiation Medicine from 2008 to 2018. Written informed consents to use biomaterial for the research purposes were obtained from all patients. Among a total of 114 patients, $49(43 \%)$ were males and 51 (57\%) - females. Imatinib for the first line TKI therapy was administrated at a dose of $400 \mathrm{mg} / \mathrm{d}$ with later escalation to $800 \mathrm{mg} / \mathrm{d}$. The second line TKI therapy was implemented with nilotinib dose $400 \mathrm{mg}$ twice a day.

Cytogenetic analysis was conducted at the time of imatinib resistance conformation. Karyotyping with standard GTG-banding was performed after a 24-hour bone marrow cells culture with no stimulation. Chromosomes were classified according to the International System for Human Cytogenetic Nomenclature [9].

Molecular response was assessed in 3, 612 months and then every 6 months during nilotinib therapy by real-time polymerase chain reaction as previously reported [10]. A complete cytogenetic response (CCR), major molecular response (MMR) and deep molecular response (MR4) were defined as BCRABL $1 / A B L$ ratios $1 \%$, $0.1 \%$, and $0.01 \%$ respectively, on the international scale. The first and second line TKI therapy responses and resistance were defined according to the ELNet 2013 recommendations [6].

The $\chi^{2}$ test and Fisher's exact test were used to compare categorical variables and the
Mann-Whitney U-test - to compare continuous variables. The probability of overall survival (OS), progression free survival (PFS), and event free survival (EFS) were estimated by the Kaplan-Meier method and compared by the log-rank test. PFS was defined as survival without signs of progression (transformation into acceleration phase or blast crisis). EFS was evaluated from the beginning of the $2^{\text {nd }}$ line therapy with nilotinib to the loss of achieved CCR or MMR, progression or death for any cause. OS was assessed from the beginning of the $2^{\text {nd }}$ line therapy till the death of any cause during the study. The cumulative probability of CCR and MMR was evaluated by the KaplanMeier method from the beginning of the $2^{\text {nd }}$ line therapy to the time of response. In this case, the data about the patients, who had not received any adequate response, with progressed disease or died, were censored at the latest observation date. Univariate analyses (Cox regression) were performed to evaluate the prognostic significance of additional chromosomal abnormalities. Statistical analysis was performed using the SPSS for Windows statistical software package (version 20.0). The results were considered significant at $\mathrm{p}<0.05$.

\section{Results}

The baseline characteristics of the patients are summarized in Table 1.

Among 114 patients, who started the second line therapy with nilotinib, 101 (88.9\%) were resistant to previous imatinib therapy. Resistance was defined as failure to achieve CCR on the first line of therapy. Twelve patients (10.5\%) achieved only CCR, while 1 (0.9\%) patient achieved MMR with previous imatinib therapy. Any achieved therapy response was completely lost in all patients with CCR and MMR by the start of nilotinib. Pathologic clone with classical t(9:22)(q34;q11) was detected in $5-100 \%$ of cells of all patients at the time of the

Table 1. CML patients' characteristics at the start of the $2^{\text {nd }}$ line therapy with nilotinib

\begin{tabular}{|l|c|c|c|c|}
\hline \multicolumn{1}{|c|}{ Patient characteristics } & $\begin{array}{c}\text { Patients with only } \\
\mathrm{t}(9 ; 22)(\mathrm{n}=96)\end{array}$ & $\begin{array}{c}\text { Patients with } \\
\mathrm{t}(9 ; \mathrm{V} ; 22)(\mathrm{n}=7)\end{array}$ & $\begin{array}{c}\text { Patients with } \\
\mathrm{ACA}(\mathrm{n}=11)\end{array}$ & $\mathrm{p}$ \\
\hline Age, median (range), years & $38(18-66)$ & $38(34-50)$ & $35(20-52)$ & 0.512 \\
\hline Sex, men, $\mathrm{n}(\%)$ & $40(41.7)$ & $3(42.9)$ & $6(54.5 \%)$ & 0.950 \\
\hline $\begin{array}{l}\text { Median of prior imatinib } \\
\text { treatment, (range), months }\end{array}$ & $\begin{array}{c}44.0 \\
(4.0-106.0)\end{array}$ & $\begin{array}{c}39,0 \\
(13.0-48.0)\end{array}$ & $\begin{array}{c}45.0 \\
(5.0-106.0)\end{array}$ & 0.578 \\
\hline $\begin{array}{l}\text { Median of follow-up on the } \\
2^{\text {nd }} \text { line therapy with nilotinib, } \\
\text { (range), months }\end{array}$ & $\begin{array}{c}52.0 \\
(4.0-106.0)\end{array}$ & $\begin{array}{c}42.0 \\
(5.0-97.0)\end{array}$ & $(1.0-79.0)$ & 0.194 \\
\hline
\end{tabular}

Notes: CML - chronic myeloid leukemia; ACA - additional chromosomal aberration 
second-line therapy initiation. The median number of $\mathrm{Ph}$-positive cells with variant translocation or with an ACA was 15\% (range of $5-100 \%$ ). The median duration of prior imatinib treatment was 43 months (range of 4 to 106 months), while the median duration of the second-line therapy monitoring was 47 months (range of 1 to 106 months).

Among a total of 114 examined patients, 18 patients (15.8\%) had ACAs at the beginning of the $2^{\text {nd }}$ line therapy with nilotinib. Seven patients $(38.9 \%)$ of 18 had variant translocations and 11 patients $(61.1 \%)$ had other chromosomal abnormalities in addition to $t(9 ; 22)$. Among the other 11, 8 patients had a single chromosomal abnormality in addition to $\mathrm{t}(9 ; 22)$, while 3 patients had multiple chromosomal abnormalities. In the majority of patients with ACAs (7 out of $11,63.6 \%$ ), an additional translocation was a second Ph-chromosome (Table 2). The patients with an isolated $t(9 ; 22)$ translocation, variant translocations or ACA were not significantly different by age, sex, and length of treatment before the beginning of the secondline therapy.
In order to evaluate the effect of ACAs on response to the second-line TKI therapy, the extent of tumor clone reduction in 12 months of therapy, the probability of CCR and MMR, as well as long-term outcomes (EFS, PFS and OS) were evaluated in all 114 patients with CML, treated with nilotinib after imatinib failure.

The presence of ACAs and variant translocations at the beginning of the $2^{\text {nd }}$ line therapy did not affect the rate of the tumor clone reduction. The CCR in 12 months (optimal response according to ELNet2013) was achieved in $37.5 \%, 42.8 \%$ and $45.5 \%(p=0.842)$ of patients with classic $\mathrm{t}(9 ; 22)$ translocation, variant translocations and ACAs respectively. In 12 months, about $50 \%$ of patients were resistant to the second line TKI therapy $(B C R / A B L>10 \%$ in 12 months of the therapy according to ELNet2013). The rate of resistance did not differ between the groups: $51.0 \%, 57.1 \%$ and $54.5 \%$ in the patients with classic $\mathrm{t}(9 ; 22)$ translocation, variant translocations and ACAs, respectively (Table 3).

No differences in the rates of disease progression and lethal outcomes were found

Table 2. Karyotypes of bone marrow cells with variant translocations and additional chromosomal aberrations in the CML patients at the beginning of nilotinib therapy $(n=18)$

\begin{tabular}{|c|c|c|c|c|}
\hline № & Sex & $\begin{array}{l}\text { Number of Ph+ } \\
\text { metaphases, \% }\end{array}$ & $\begin{array}{l}\text { Number of } \\
\text { metaphase } \\
\text { with ACA, \% }\end{array}$ & Karyotype \\
\hline 1 & $\mathrm{~F}$ & 95 & 100 & 46,XX,t(9;22;?)(q34;q11;?)[19] 46,XX[1] \\
\hline 2 & $\mathrm{~F}$ & 100 & 100 & $46, X X, t(5 ; 9 ; 22)(q 31 ; q 34 ; q 11)[20]$ \\
\hline 3 & $\mathrm{~F}$ & 100 & 5 & $46, X X, t(9 ; 22)(q 34 ; q 11)[19] /$ idem, $+\operatorname{der}(22) t(9 ; 22)[1]$ \\
\hline 4 & $\mathrm{M}$ & 73 & 53,3 & $46, X Y, t(9 ; 22)(q 34 ; q 11)[3] / i d e m,+\operatorname{der}(22) t(9 ; 22)[8] / 46, X Y[4]$ \\
\hline 5 & $\mathrm{M}$ & 100 & 100 & $46, X Y, t(6 ; 9 ; 22)(p 22 ; q 34 ; q 11)[20]$ \\
\hline 6 & $\mathrm{~F}$ & 100 & 100 & 46,XX,der(9)t(9;?;22)(q34;?;q11)[20] \\
\hline 7 & $\mathrm{M}$ & 85 & 5 & $\begin{array}{c}46, X Y, t(9 ; 22)(q 34 ; q 11)[5] / \text { idem, }+\operatorname{der}(22) t(9 ; 22) \\
{[1] / 46, X Y[14]}\end{array}$ \\
\hline 8 & $\mathrm{M}$ & 100 & 70 & $\begin{array}{c}46, \mathrm{XY}, \mathrm{t}(9 ; 22)(\mathrm{q34} ; \mathrm{q} 11)[6] / \mathrm{idem},+\operatorname{der}(22) \mathrm{t}(9 ; 22)[11] / \\
\text { idem,+der(22)t(9;22),+7[3] }\end{array}$ \\
\hline 9 & $\mathrm{M}$ & 100 & 100 & $47, X Y, t(9 ; 22)(q 34 ; q 11),+\operatorname{der}(22) t(9 ; 22)[14] /$ idem,+12[2] \\
\hline 10 & $\mathrm{~F}$ & 50 & 42,5 & $\begin{array}{c}47, \mathrm{XX}, \mathrm{t}(9 ; 22)(q 34 ; q 11),+\operatorname{der}(22) \mathrm{t}(9 ; 22)[17] / 46, \mathrm{XX}, \mathrm{t}(9 ; 22) \\
(q 34 ; q 11)[13] / 46, \mathrm{XX}[20]\end{array}$ \\
\hline 11 & $\mathrm{M}$ & 30 & 30 & 46, XY,t(3;9;22)(p25;q34;q11)[6] /46,XY[14] \\
\hline 12 & $\mathrm{~F}$ & 100 & 30 & $47, X X, t(9 ; 22)(q 34 ; q 11),+3[6] / 46, X X, t(9 ; 22)(q 34 ; q 11)[14]$ \\
\hline 13 & M & 20 & 100 & $\begin{array}{l}46 \sim 48, X Y, t(9 ; 22)(q 34 ; q 11)[4], \operatorname{del}(10)(p 11.2)[5] \\
\quad+12[2],+13[12],+14[2]+15[4][\mathrm{cp} 20]\end{array}$ \\
\hline 14 & $\mathrm{~F}$ & 100 & 100 & $46, X X, t(3 ; 21)(q 26.2 ; q 22), t(9 ; 22)(q 34 ; q 11)[20]$ \\
\hline 15 & $\mathrm{M}$ & 100 & 100 & $46, X Y, t(9 ; 21 ; 22 ;)(q 34 ; q 22.2 ; q 11)[20]$ \\
\hline 16 & $\mathrm{~F}$ & 100 & 5 & $46, X X, t(9 ; 22)(q 34 ; q 11)[19] /$ idem, $+\operatorname{der}(22) t(9 ; 22)[1]$ \\
\hline 17 & M & 90 & 5 & $\begin{array}{c}46, X Y, t(9 ; 22)(q 34 ; q 11)[17] / \\
\text { idem,+der(22)t(9;22)[1]/46,XY[2] }\end{array}$ \\
\hline 18 & $\mathrm{~F}$ & 100 & 100 & $46, X X, t(1 ; 9 ; 22)(q 21.2 ; q 34 ; q 11)[20]$ \\
\hline
\end{tabular}

Notes: ACA - additional chromosomal aberration. 
Table 3. Response to the $2^{\text {nd }}$ line nilotinib therapy in the CML patients depending on the presence of additional chromosomal aberrations

\begin{tabular}{|c|c|c|c|c|}
\hline Characteristics & $\begin{array}{l}\text { Patients with } \\
\text { only } t(9 ; 22) \\
(n=96)\end{array}$ & $\begin{array}{l}\text { Patients with } \\
\mathrm{t}(9 ; \mathrm{V} ; 22)(\mathrm{n}=7)\end{array}$ & $\begin{array}{l}\text { Patients with } \\
\text { ACA }(n=11)\end{array}$ & $\mathrm{p}$ \\
\hline $\begin{array}{l}\text { Response in } 12 \text { months of the } 2^{\text {nd }} \text { line } \\
\text { nilotinib therapy: } \\
\text { CCR }(B C R / A B L 1 \leq 1 \%), n(\%) \\
\text { MMR }(B C R / A B L 1 \leq 0.1 \%), n(\%) \\
\text { BCR/ABL } 1>10 \%, n(\%)\end{array}$ & $\begin{array}{l}36(37.5) \\
13(13.5) \\
49(51.0) \\
\end{array}$ & $\begin{array}{l}3(42.8) \\
1(14.3) \\
4(57.1)\end{array}$ & $\begin{array}{l}5(45.5) \\
3(27.3) \\
6(54.5)\end{array}$ & $\begin{array}{l}0.842 \\
0.516 \\
0.938 \\
\end{array}$ \\
\hline $\begin{array}{l}\text { Secondary resistance: } \\
\text { MMR loss, n (\%) } \\
\text { CCR loss, n (\%) } \\
\text { Progression to AP or BC, n (\%) }\end{array}$ & $\begin{array}{c}4 / 30(13,3) \\
4 / 46(8.7) \\
19(19.8) \\
\end{array}$ & $\begin{array}{l}0 / 2(0) \\
0 / 4(0) \\
1(14.3)\end{array}$ & $\begin{array}{l}1 / 5(20) \\
0 / 5(0) \\
2(18.2)\end{array}$ & $\begin{array}{l}0.829 \\
0.656 \\
0.934\end{array}$ \\
\hline Number of lethal outcomes, n (\%) & $17(17.7)$ & $1(14.3)$ & $1(9.1)$ & 0.756 \\
\hline
\end{tabular}

Notes: CML - chronic myeloid leukemia; ACA - additional chromosomal aberration; CCR - complete cytogenetic response; MMR - major cytogenetic response, AP - acceleration phase; BC - blast crisis.

between the patients with classic $t(9 ; 22)$ translocation, variant translocations and ACAs (Table 3). For the whole follow-up period, the only case of progression to accelerated phase with a lethal outcome took place in one patient with variant translocation of unknown origin $\mathrm{t}(9 ; ? ; 22)(\mathrm{q} 34 ; ? ; \mathrm{q} 11)$ and in one patient with three related clones: $30 \%$ metaphases with isolated $\mathrm{Ph}$-chromosome, 55\% metaphases with an additional Ph-chromosome, and 15\% of metaphases with two Ph-chromosomes and an extra chromosome 7 . Karyotype $46, \mathrm{XY}, \mathrm{t}(9 ; 22)$ (q34;q11)[6]/idem,+der(22)t(9;22)[11]/ idem,+der(22)t(9;22),+7[3].

Kaplan-Meier analysis of the long-term outcomes of the $2^{\text {nd }}$ line nilotinib therapy proved an absence of significant influence of the ACA and variant translocation status at the beginning of the $2^{\text {nd }}$ line nilotinib therapy on the three-year EFP, PFS and OS (Table 4).

Despite the ACAs at the beginning of the $2^{\text {nd }}$ line therapy did not affect the nilotinib efficacy, quantitative characteristics of the leukemic clone did have prognostic value. A positive correlation between the amount of Ph-positive clone before the beginning of the $2^{\text {nd }}$ line nilotinib therapy and development of resistance (BCR/ABL1>10\%) in 12 months of the subsequent therapy (Spearman correlation coefficient $r=0.423, p<0.001$ ) was found. The increase in the number of Ph-positive cells at the beginning of the nilotinib therapy and increase in size of the additional clone (percent metaphases with ACA) was associated with the decreased efficiency of tumor clone reduction during the therapy, or more specifically, statistically significant decrease in the rate of CCR $(p<0.001$, $p=0.049$ ). In other words, the efficacy of the second line TKI therapy in the imatinib-resistant CML patients was associated with the level of reduction of the tumor clone and the size of the clone with additional aberrations before the beginning of the second-line therapy (Table 5).

\section{Discussion}

Studies of the ACA prognostic value both in the era before the TKI and after approving of the first TKI imatinib indicate that the ACA

Table 4. Long-term outcomes of the $2^{\text {nd }}$ line nilotinib therapy in the CML patients depending on the presence of additional chromosomal aberrations

\begin{tabular}{|c|c|c|c|c|}
\hline Outcomes & $\begin{array}{c}\text { Patients with only } \\
\mathrm{t}(9 ; 22)(\mathrm{n}=96)\end{array}$ & $\begin{array}{c}\text { Patients with } \\
\mathrm{t}(9 ; \mathrm{V} ; 22)(\mathrm{n}=7)\end{array}$ & $\begin{array}{c}\text { Patients with ACA } \\
(\mathrm{n}=11)\end{array}$ & $\mathrm{p}$ \\
\hline 3-year EFS, \% (95\% CI) & $\begin{array}{c}80.1 \\
(71.5-88.7)\end{array}$ & $\begin{array}{c}80.0 \\
(45.5-100.0)\end{array}$ & $\begin{array}{c}74.1 \\
(42.5-100.0)\end{array}$ & 0.468 \\
\hline 3-year PFS, \% (95\% CI) & $\begin{array}{c}86.4 \\
(79.1-93.7)\end{array}$ & $\begin{array}{c}76.0 \\
(45.5-100.0)\end{array}$ & 0.936 \\
\hline 3-year OS, \% (95\% CI) & 90.7 & 80.0 & 85.7 & 0.975 \\
\hline
\end{tabular}

Notes: CML - chronic myeloid leukemia, ACA - additional chromosomal aberration, CI - confidence interval, EFS - event free survival, PFS - progression free survival, OS - overall survival. 
Table 5. Estimation of the significance of ACA clones quantitative characteristics in the CML patients $(n=18)$ at the beginning of the $2^{\text {nd }}$ line nilotinib therapy for the probability of CCR, EFS, PFS and $O S$ by the univariate Cox regression analyses

\begin{tabular}{|l|c|c|c|c|c|c|c|c|}
\hline \multirow{2}{*}{$\begin{array}{l}\text { Characte- } \\
\text { ristics }\end{array}$} & \multicolumn{2}{|c|}{ CCR } & \multicolumn{2}{c|}{ EFS } & \multicolumn{2}{c|}{ PFS } & \multicolumn{2}{c|}{ OS } \\
\cline { 2 - 8 } & $\begin{array}{c}\operatorname{Exp}(\mathrm{B}) \\
95 \mathrm{CI})\end{array}$ & $\mathrm{p}$ & $\begin{array}{c}\operatorname{Exp}(\mathrm{B}) \\
(95 \% \mathrm{CI})\end{array}$ & $\mathrm{p}$ & $\begin{array}{c}\operatorname{Exp}(\mathrm{B}) \\
(95 \% \mathrm{CI})\end{array}$ & $\mathrm{p}$ & $\begin{array}{c}\operatorname{Exp}(\mathrm{B}) \\
(95 \% \mathrm{CI})\end{array}$ & $\mathrm{p}$ \\
\hline $\begin{array}{l}\text { \% Ph+ } \\
\text { metaphases }\end{array}$ & $\begin{array}{c}0.981 \\
(0.971-0.990)\end{array}$ & $<0.001$ & $\begin{array}{c}1.027 \\
(1.00-1.054)\end{array}$ & 0.039 & $\begin{array}{c}1.037 \\
(1.000-1.076)\end{array}$ & 0.052 & $\begin{array}{c}1.062 \\
(0.997-1.132)\end{array}$ & 0.062 \\
\hline $\begin{array}{l}\text { \% meta- } \\
\text { phases with } \\
\text { ACA }\end{array}$ & 1.041 & 0.049 & $\begin{array}{c}1.028 \\
(1.000-.083)\end{array}$ & 0.268 & $\begin{array}{c}1.031 \\
(0.979-1.085)\end{array}$ & 0.248 & $\begin{array}{c}1.025 \\
(0.973-1.080)\end{array}$ & 0.354 \\
\hline
\end{tabular}

Notes: CML - chronic myeloid leukemia; ACA - additional chromosomal aberration; CI - confidence interval; EFS - event free survival; PFS - progression free survival; OS - overall survival.

presence in the therapy worsens the treatment results and decreases patient survival [11-13]. Some disagreements are observed in assessment of the ACA significance at the time of diagnosis. Alhuraiji A., et al. in the prospective clinical study on $603 \mathrm{CP} C M L$ patients pointed out that the presence of ACA at the time of diagnosis was not associated with worse prognosis [14]. Fabarius, et al. consider that only major route, but not balanced or unbalanced minor route ACA has a negative impact on prognosis of CML [13]. Wang et al. also underline that variability in outcomes is related to the type of ACA, but they suggest another ACA stratification system. 'Poor prognosis' for ACA including $\mathrm{i}(17)(\mathrm{q} 10),-7 /$ del7q, and 3q26.2 rearrangements as well as presence of 2 or more ACAs conferred a worse survival irrelevant to the emergence phase and time. In contrast, ACAs in group of 'good prognosis' including trisomy $8,-Y$, and an extra copy of Ph-chromosome had no adverse impact on survival, when they emerged at the chronic phase or at the time of CML diagnosis [15].

Nilotinib is more potent and selective ATPcompetitive inhibitor of BCR/ABL1 tyrosine kinase than imatinib and it is more active against imatinib-resistant mutant forms of enzyme $[16,17]$. Multicenter trials and a real-life longitudinal proved nilotinib efficacy in the CML patients with imatinib failure $[8,18]$.

Our report presents outcomes after the second line therapy with nilotinib in the CML patients with imatinib failure depending on the presence of variant translocations or clonal evolution at the beginning of the $2^{\text {nd }}$ line therapy with nilotinib. Among a total of 114 examined patients, 18 patients (15.8\%) had clonal evolution at the beginning of nilotinib.
Seven patients (38.9\%) of 18 had variant translocations and 11 patients $(61.1 \%)$ had clonal evolution - additional to $\mathrm{t}(9 ; 22)$ chromosomal abnormalities. Our results suggest that for the patients with variant translocations $t(9 ; \mathrm{V} ; 22)$ or clonal evolution treated with nilotinib after imatinib failure, the CCR and MMR response, EFS, PFS and OS rates do not differ from those of the CML patients with $t(9 ; 22)$ only. At the same time quantitative characteristics of leukemic and ACA clones have a significant impact on CCR. The greater number of Ph-positive cells and the number of cells with the ACA are revealed at the beginning of nilotinib, the less - for CCR probability. EFS is also worse with increasing number of $\mathrm{Ph}$ positive cells at the beginning of nilotinib. The significance of certain types of ACA for longterm outcomes has not been investigated because of small groups of patients with different ACAs.

\section{Conclusions}

The presence of ACA provides the tumor with heterogeneous properties that determine its sensitivity to therapy. But higher inhibitory activity of nilotinib compare to the imatinib allows overcoming imatinib resistance in the CML patients regardless of the ACA presence and achieves CCR in about $50 \%$ of patients in 12 months of nilotinib therapy. Investigation of prognostic value of the combination ACA with other tumor clone features advantages development of criteria for the individual selection of TKI in the resistant patients.

\section{Conflicts of Interest}

Authors declare no conflict of interest. 


\title{
ЗНАЧЕННЯ ДОДАТКОВИХ ХРОМОСОМНИХ АБЕРАЦІЙ У ФОРМУВАННІ ВІДПОВІДІ НА ДРУГУ ЛІНІЮ ТЕРАПІЇ НІЛОТИНІБОМ У ХВОРИХ НА ХРОНІЧНУ МІЄЛОЇДНУ ЛЕЙКЕМІЮ
}

\author{
І.В. Дмитренко, Ж.М. Мінченко, В.Г. Федоренко, І.С. Дягіль \\ ДУ “НАЦІОНАЛЬНИЙ НАУКОВИЙ ЦЕНТР РАДІАЦІЙНОЇ МЕДИЦИНИ НАЦІОНАЛЬНОЇ \\ АКАДЕМІЇ МЕДИЧНИХ НАУК УКРАЇНИ", КИЇВ, УКРАЇНА
}

Вступ. Існує обмежена інформація про вплив додаткових хромосомних аберацій (ДХА) на ефективність терапії нілотінібом другої лінії у хворих з хронічною мієлодною лейкемією (ХМЛ).

Мета: проаналізувати значущість ДХА щодо відповіді на терапію інгібіторами тирозинкіназ (ITK) другої лінії (нілотинібом) у хворих на ХМЛ, у яких терапія іматинібом була неефективною.

Методи. Аналізували ефективність терапії нілотинібом у хворих на ХМЛ в хронічній фазі, у яких терапія іматинібом була неефективною.

Результати. Серед 114 пацієнтів 18 пацієнтів (15,8\%) мали ДХА на початку 2-ї лінії терапії нілотінібом. Сім пацієнтів (38,9\%) з 18 мали варіантні транслокації, а 11 пацієнтів (61,1\%) мали інші хромосомні аномалії, крім t(9;22), тобто ознаки клональної еволюції. Повна цитогенетична відповідь (ПЦВ) через 12 місяців терапії нілотинібом була досягнута у 37,5\%, 42,8\% і 45,5\% (p=0,842) пацієнтів 3 класичною транслокацією t(9;22), варіантними транслокаціями та клональною еволюцією відповідно. У пацієнтів з варіантнимии транслокаціями $t(9 ; \mathrm{V} ; 22)$ та клональною еволюцією швидкість ПЦВ та великої молекулярної відповіді (BMB), безподійна виживаність (EFS), виживаність без прогресії (PFS) та загальна виживаність (OS) не відрізнялися від таких у хворих на ХМЛ, у яких виявлялась тільки транслокація $t(9 ; 22)$. В той же час, кількісні характеристики лейкемічного клону та клону з ДХА мали прогностичне значення щодо досягнення ПЦВ. Збільшення кількості Ph-позитивних клітин та клітин з ДХА на початку терапії нілотинібом зменшувало вірогідність досягнення ПЦВ.

Висновки. Більш висока інгібуюча активність нілотинібу в порівнянні з іматинібом дозволяє подолати резистентність до іматинібу у пацієнтів з ХМЛ незалежно від наявності ДХА на початку терапії нілотинібом.

КЛЮЧОВІ СЛОВА: додаткові хромосомні аберації; хронічна мієлоїдна лейкемія; нілотиніб; друга лінія терапії ITK (інгібітори тирозинкіназ); прогнозування; резистентність.

Інформація про авторів

Дмитренко Ірина Віталіївна - канд. біол. наук, старший науковий співробітник лабораторії імуногенетики відділу гематології та трансплантології, ДУ “Національний науковий центр радіаційної медицини Національної академії медичних наук України".

Мінченко Жанна Миколаївна - д-р біол. наук, професор, завідувач лабораторії імуногенетики відділу гематології та трансплантології, ДУ “Національний науковий центр радіаційної медицини Національної академії медичних наук України".

Федоренко Віра Григорівна - молодший науковий співробітник лабораторії імуногенетики відділу гематології та трансплантології, ДУ “Національний науковий центр радіаційної медицини Національної академії медичних наук України".

Дягіль Ірина Сергіївна - д-р мед. наук, завідувач відділення радіаційної онкогематології та трансплантації стовбурових клітин відділу гематології та трансплантології, ДУ “Національний науковий центр радіаційної медицини Національної академії медичних наук України”.

\section{Information about the authors}

Iryna V. Dmytrenko - Ph.D., Senior Researcher, Immunogenetic Laboratory, Hematology and Transplantology Department, State Institution "National Research Center for Radiation Medicine of the National Academy of Medical Sciences of Ukraine", Kyiv, Ukraine.

ORCID 0000-0002-2136-5442, e-mail: iryna.v.dmytrenko@gmail.com

Zhanna M. Minchenko - Doctor of Biological Science, Professor, Head of the Immunogenetic Laboratory, Hematology and Transplantology Department, State Institution "National Research Center for Radiation Medicine of the National Academy of Medical Sciences of Ukraine", Kyiv, Ukraine.

Vira V. Fedorenko - Researcher, Immunogenetic Laboratory, Hematology and Transplantology Department, State Institution "National Research Center for Radiation Medicine of the National Academy of Medical Sciences of Ukraine", Kyiv, Ukraine.

Iryna S. Dyagil - Doctor of Medical Science, Head of the Radiation Oncohematology and Transplantology Department, State Institution “National Research Center for Radiation Medicine of the National Academy of Medical Sciences of Ukraine", Kyiv, Ukraine. 


\section{References}

1. Faderl S, Talpaz M, Estrov Z, O'Brien S, Kurzrock R, Kantarjian HM. The biology of chronic myeloid leukemia. N Engl J Med. 1999;341:164-172.

doi: 10.1056/NEJM199907153410306

2. Zaccaria A, Testoni N, Valenti AM, Luatti S, Tonelli M, Marzocchi G et al. Chromosome abnormalities additional to the Philadelphia chromosome at the diagnosis of chronic myelogenous leukemia: pathogenetic and prognostic implications. Cancer Genet Cytogenet. 2010;199(2):76-80.

doi: $10.1016 / j$.cancergencyto.2010.02.003

3. Mitelman F. The cytogenetics scenario of chronic myeloid leukemia. Leuk Lymphoma. 1993;11(Suppl 1):11-15.

doi: $10.3109 / 10428199309047856$

4. Cortes J., O'Dwyer M.E. Clonal evolution in chronic myelogenous leukemia. Hematol Oncol Clin N Am. 2004;18(3):671-84.

doi: 10.1016/j.hoc.2004.03.012

5. Luatti S, Castagnetti F, Marzocchi G, Baldazzi C, Gugliotta G, Iacobucci I, Specchia G, Zanatta L, RegeCambrin G, Mancini M, Abruzzese E. Additional chromosomal abnormalities in Philadelphia-positive clone: adverse prognostic influence on frontline imatinib therapy: a GIMEMA Working Party on CML analysis. Blood. 2012 Jul 26;120(4):761-7.

doi: 10.1182/blood-2011-10-384651

6. Baccarani M, Deininger MW, Rosti G, Hochhaus A, Soverini S, Apperley JF et al. European LeukemiaNet recommendations for the management of chronic myeloid leukemia. Blood. 2013;122:872884.

doi: 10.1182/blood-2013-05-501569

7. Nicolini FE, Turkina A, Shen ZX, Gallagher N, Jootar S, Powell BL et al. Expanding Nilotinib Access in Clinical Trials (ENACT): an open-label, multicenter study of oralnilotinib in adult patients with imatinibresistant or imatinib-intolerant Philadelphia chromosome-positive chronic myeloid leukemia in the chronic phase. Cancer. 2012;118(1):118-126.

doi: 10.1002/cncr.26249

8. Cony-Makhoul P, Gardembas M, Coiteux V, Carpentier N, Pommier C, Violet I et al. Nilotinib after imatinib first-line: a real-life longitudinal cohort of patients with chronic myeloid leukaemia in chronic phase. British Journal of Haematology. 2018;180:356364.

doi: 10.1111/bjh.15042

9. Shaffer LG, McGowan-Jordan J, Schmid M. ISCN 2013: An International System for Human Cytogenetic Nomenclature (2013). Basel. Karger; 2013:140 p.

doi: $10.3390 / \mathrm{s} 130201593$

10. Cortes J, Talpaz M, O'Brien S, Jones D, Luthra R, Shan J et al. Molecular responses in patients with chronic myelogenous leukemia in chronic phase treated with imatinib mesylate. Clin Cancer Res. 2005;11:3425-3432.

doi: 10.1158/1078-0432.CCR-04-2139

11. Kantarjian HM, Smith TL, McCredie KB, Keating MJ, Walters RS, Talpaz M et al. Chronic myelogenous leukemia: a multivariate analysis of the associations of patient characteristics and therapy with survival. Blood. 1985;66(6):1326-1335.

12. Farag SS, Ruppert AS, Mrózek K, Carroll AJ, Pettenati MJ, Le Beau MM et al. Prognostic significance of additional cytogenetic abnormalities in newly diagnosed patients with Philadelphia chromosomepositive chronic myelogenous leukemia treated with interferon-alpha: A Cancer and Leukemia Group B study. Int J Oncol. 2004;25(1):143-151.

doi: 10.3892/ijo.25.1.143

13. Fabarius A, Leitner A, Hochhaus A, Müller MC, Hanfstein B, Haferlach C et al. Impact of additional cytogenetic aberrations at diagnosis on prognosis of CML: long-term observation of 1151 patients from the randomized CML Study IV. Blood. 2011;118(26): 6760-6768.

doi: 10.1182/blood-2011-08-373902

14. Alhuraiji A, Kantarjian H, Boddu P, Ravandi F, Borthakur G, DiNardo C et al. Prognostic significance of additional chromosomal abnormalities at the time of diagnosis in patients with chronic myeloid leukemia treated with frontline tyrosine kinase inhibitors. Am J Hematol. 2018;93:84-90.

doi: 10.1002/ajh.24943

15. Wang W, Cortes JE, Tang G, Khoury JD, Wang S, Bueso-Ramos CE et al. Risk stratification of chromosomal abnormalities in chronic myelogenous leukemia in the era of tyrosine kinase inhibitor therapy. Blood. 2016;127(22):2742-2750.

doi: 10.1182/blood-2016-01-690230

16. Manley PW, Stiefl N, Cowan-Jacob SW, Kaufman S, Mestan J, Wartmann M et al. Structural resemblances and comparisons of the relative pharmacological properties of imatinib and nilotinib. Bioorg Med Chem. 2010;18:6977-6986.

doi: 10.1016/j.bmc.2010.08.026

17. O'Hare T, Walters DK, Deininger MW, Druker BJ. AMN107: tightening the grip of imatinib. Cancer Cell. 2005;7:117-119.

doi: 10.1016/j.ccr.2005.01.020

18. Kantarjian HM, Giles FJ, Bhalla KN, PinillaIbarz J, Larson RA, Gattermann N et al. Nilotinib is effective in patients with chronic myeloid leukemia in chronic phase after imatinib resistance or intolerance: 24-month follow-up results. Blood. 2011;117(4):1141-1145.

doi: 10.1182/blood-2010-03-277152

Received 05 May 2019; revised 19 May 2019; accepted 05 June 2019.

This is an open access article distributed under the Creative Commons Attribution License, which permits unrestricted use, distribution, and reproduction in any medium, provided the original work is properly cited. 